\title{
Sir Frank Fraser Darling DSc, FRSE, 1903-1979
}

Richard Fitter writes:

With the death of Frank Fraser Darling on October 22, the Society, and the world, has lost the greatest of the first generation of applied ecologists. Fraser Darling learned his ecology in the days when Tansley's Types of British Vegetation (1911) had made hardly any impact on the botanical establishment, and Elton's Animal Ecology (1927) even less on the zoological. He first made his impact on the public with his field study of $A$ Herd of Red Deer (1937), the beginning of a process whereby a Yorkshire man took on the cloak of an eminent Scot. He followed this up with a series of excellent books based on his field studies in the West Highlands, culminating in his magisterial West Highland Survey (1955), a book far ahead of its time in its treatment of man as part of the ecosystem. In 1959, through the influence of Fairfield Osborn, then a VicePresident of FPS, he became a Vice-President of the (US) Conservation Foundation, and was launched on the international scene. Here he extended his percipient studies of natural and human ecology to Alaska, Zambia and other parts of the world, and his Wildlife in African Territory (1960), about Zambia, is in many ways his best book.

Fraser Darling's last stage as an ecological sage of the world scene began with his Reith Lectures in 1969, followed by membership of the Royal Commission on Environmental Pollution and of the then Nature Conservancy (UK). In his early days something between a rebel and a crank in the eyes of the establishment, he lived to see himself transformed into a universal guru, in no small part as a result of his own teachings and writings. $\mathrm{He}$ wrote 26 books, gave innumerable lectures, served on the governing bodies of many organisations - FPS Council 1954-1970, Vice-President 1970-1979 - and received many honours, both civil and academic. He was a great man, perhaps greater than any naturalist since Darwin.

\section{FPS Annual General Meeting}

Professor Kai Curry-Lindahl, an FPS Vice-President and Environmental Advisor to the Swedish Government, was the speaker at the Annual General Meeting on July 4. His address, 'Is Aid to Developing Countries Destroying Their Environment?', is given in full on page 133. The President, Lord Zuckerman, was in the chair. David Attenborough was elected a Vice-President of the Society, and three new Council members, R. E. Boote, J. Hancock and Dr R. E. Stebbings, were elected to replace the three retiring members, Dr E. Barton Worthington, Dr G. C. L. Bertram and Dr David Harrison, who were warmly thanked by the President for their services. The six Officers of the Society were re-elected, and the Annual Report and Accounts were approved.

The meeting approved Council's proposals for raising membership subscriptions to $£ 10$ for ordinary members, $£, 20$ for benefactors and $£, 5$ for students; life members' subscriptions are to be raised to $£ 350$ for those aged 41 and under, $£ 300$ for $41-60$, and $£ 150$ for 60 and over. The Hon. Treasurer said that it was with great reluctance that Council had taken this step. But the escalation in costs makes it inevitable.

The Vice-Chairman, Lord Craigton, proposed a vote of thanks to FPS staff for devoted service, and Sir Peter Scott thanked the Zoological Society of London for continuing to provide office accommodation and other services and assistance during the year. After a wine and cheese supper, a film, Saga of the Sea Otter, was shown, and members were able to participate in a Zoo open evening. 